\title{
Organizing and Knowing: Finding Approaches in a Processual Manner
}

\author{
Camilla Zanon Bussular \\ Universidade Federal do Rio Grande do Sul - RS - Brazil \\ camilla.zanon@gmail.com \\ orcid.org/0000-0002-9233-7481 \\ Claudia Simone Antonello \\ Universidade Federal do Rio Grande do Sul - RS - Brazil \\ claudia.antonello@ufrgs.br \\ orcid.org/oooo-0001-9654-5125
}

\begin{abstract}
The processual-political dimension is considered a gap in organizational learning literature, because it has been little explored in theoretical and empirical terms (Antonello \& Godoy, 2011). Thus, this theoretical essay aims to discuss the possibility of joining the two terms from a processual and political perspective, here named organizational learning processes. With contribution from authors who worked on the notion of organizingknowing-learning as a process (Gherardi, 2001, 2005, 2009, 2010, 2011, Nicolini et al., 2005, 2011), and of practices (Schatzki, 2001, 2006; Gherardi, 2005, 2011), processes of organizational learning are collective ways of doing, they are moving and unstable, cognizable by learning and knowing. They are established in a network of heterogeneous relations in multiple forms of spatialities, and they can be inscribed and form textures of practices, whose conditions for possibilities for achievement and participation are not given, also serving as a means to combat, overcome inequalities, and to form other doings and practices.
\end{abstract}

Keywords: organizational learning, practice-based approach, political ontology, organizing 
The interest in the subject of learning in organizational studies has been developed academically for several decades. The first texts that deal with learning and organization together are from the early 1950s, but gained greater prominence from the 6os (Cangelosi \& Dill, 1965; Cyert \& March, 1963) and 70s (Argyris \& Schön, 1978; March \& Olsen, 1975). Cyert \& March's work (1963) is ascribed as being the first time the term organizational learning was used side by side, as basis for a business decision model, and the work of Cangelosi \& Dill (1965) as the first time the conjugated term composed the cover of a publication, arguing against the excessive rationality presented by pioneering authors in decision-making processes (Easterby-Smith \& Lyes, 2011). Almost thirty years later, from the 9os onwards, there has been exponential growth of publications and in the search for the topic of learning in its relation to studies on organizations (Crossan \& Guatto, 1996; Antonello \& Godoy, 2011).

Numerous forums and conceptual discussions have taken place in the field of organizational studies of learning to discuss what turns out to be, after all, the so called organizational learning (OL), which is set as the meeting of learning with the organization and of the organization with learning. The terms have already had this order modified to be understood as learning organizations (Easterby-Smith \& Araujo, 2001). This discussion has already been remade by academics of the area and overcome since it is primarily directed to the utilitarian character of learning. Consensus in the field is that there is no consensus on the notion of organizational learning (Nicolini \& Meznar, 1995; Flach \& Antonello, 2011; Easterby-Smith \& Lyes, 2011). Different epistemological and ontological traditions present different visions regarding the object of study (in such case, learning and organization), creating different narratives about it (Gherardi \& Nicolini, 2001). Several reviews on the topic have been made over the years (Shrivastava， 1983； Fiol \& Lyes， 1985； Levitt \& March， 1988； Easterby-Smith， 1997; Dodgson, 1993; Babuji \& Crossan, 2004). In Brazil, it is important to mention Antonello \& Godoy's (2011) review on the subject, demonstrating the roots of the polysemy of the term OL.

The predominant concepts in the area are influenced by traditional perspectives of management, inspired by presuppositions from the functional-structuralist-systemic epistemological triad. In spite of great influence from a psychological-individual perspective, narrative on organizational learning (OL) is multiplied by several theoretical traditions and areas of knowledge, inspired by different epistemologies: sociology, 
anthropology, political science, history, economics and administration (Antonello \& Godoy, 2011). There are four relevant aspects, still little debated in the theoretical aspects of learning, which deserve to be part of the discussions on organizational learning. The first aspect concerns the level of learning. No matter the level of representation (organizational, interorganizational or group) learning always resorts to the subject and his/her relationships. The second aspect regards the neutrality of the learning goal. Although often related to a positive dimension, learning can be considered bad (stealing and killing, for instance, are considered crimes in the legal and social system of various societies, but they are often learned and practiced). The third aspect relates to the idea of change, because not all learning is expressed in behavioral change. Finally, there is the processual aspect of learning and organization, which is the most promising for the development of the concept (Antonello \& Godoy, 2011). It is not the process commonly known in administration - inputs, processing and results - but a process based on relationships and actions that are in flux, in everyday practical situations.

In order to explore the potential of learning as process and the gap in the literature, this theoretical essay aims to discuss the possibility of joining the two terms from a processual and political perspective, in this work named organizational learning processes. Thus, we will discuss the processual and relational aspects to present what is understood as organization and learning. In the next sections, we will explore the notion of organizing and the notion of knowing getting to a final debate on the joint understanding of the terms in a processual perspective.

\section{Organizing}

What do you understand by organization? This is a question that should be asked more often among business academics. In most of the works, this seems to be a given concept, presupposed and that does not "need" or even "deserve" to be questioned (Duarte \& Alcadipani, 2016). Once, we were questioned: "Isn't it obvious?" The answer was: "No, it is not, and should never be." Truism carries within itself the postulate of a unique and exclusive way of thinking, a political game reaffirmed in the academic relations of discussion and in the national and international journal publications.

In the dominant view of the field, organization is understood as a structure, a system that is limited and rationally oriented to the achievement of outlined goals, from the 
gathering of people; a social tool and extension of human rationality (Cooper \& Burrell, 1988). Likewise, organization is not understood in terms of flow, emotion and unpredictability. Rather, it is seen as a means of imposing control and structure to the existing chaotic world. People need to create a sense of order to feel secure and the organization provides the means to achieve this stable, predictable, and secure mode of the world. Traditionally, the organization must be singular in its totality, systematic, integrated, ordering multiplicity. Nothing emotional or messy may and should be institutionalized (Clegg et al., 2005). It is assumed that notions such as organization, objectives, culture, environment, strategies, life cycles, among others, are theoretically legitimized objects of organizational analysis (Chia, 1996).

Modern and postmodern views can be considered as different "styles of thought" (Chia, 1996) within organizational studies, thus producing different ways of intuiting what organization is about. These styles influence modes of thinking, each with its ontological commitments, intellectual priorities, and ways of theorizing. One style assumes the being ontology and the other a becoming ontology (Chia, 1996). The being ontology, present in traditional theories or theories bearing the "modern style of thought", takes on the ontological assumption of the organization that objectively exists, $a$ priori, as static, discrete, and identifiable worlds (Chia,1996). Its objects are uncritical and nonconflicting. Properties like unity, identity, permanence, structures and essences are privileged in this analysis of the world and of organizations (Chia, 1996). Approaches such as Systems Theory, Costs and Transaction, Population Ecology, as well as other areas of the administration field tend to assume the being ontology in its organizational apprehension (Duarte \& Alcadipani, 2016).

Since the 1970s, organizational studies have opened up to discuss postmodern and poststructuralist ideas (Calás \& Smircich, 1999). Cooper (1976) in his text "Open Field" defines the epistemology of the process as basis for the development of expressive and creative action. The process is understood in terms of flow of actions, relations and changes. It can be understood as a movement of instabilities, tensions and contradictions, where movements can occur backwards and forwards. The nature of this flow of actions, relations and changes is political. The concept of political ontology (Mol, 1999) refers to how the world is implicated in politics and how politics is implicated in the world. It is also a compound term. On philosophy, ontology signifies what belongs to the real and the conditions of possibility negotiated between actors. The combination of the term 
"ontology" with "politics" suggests that conditions of possibility are not given. They are performed, challenged and enacted during their production. Reality does not precede practices in which people interact and create their worlds. Thus, politics represents this active process of production of realities, being at the same time open and liable to be contested (Mol, 1999). The concept of political ontology is an assertion that things can happen otherwise and that realities are not destinies (Law, 2007). Therefore, realities changes, are contested and in some point they could be otherwise.

The "Open Field" text was one of the seminal ones for organizational studies, in the discussion of the idea of process, and for an opening to the becoming ontology and construction of reflective knowledge. In the sociology of becoming, static entities and those unchallenged by the sociology of being come to be seen as effects of complex social processes. The differentiation between being and becoming is basic to the use of the terms distal (effects of the sociology of being) and proximal (effects of the sociology of becoming or of process) as modes of thinking organizational analysis (Cooper \& Law, 1995).

The postmodern style of thought in organizational studies focuses its analysis on the ontology of relational movements, on emergence and becoming, where the ephemeral and transient features of the real are accentuated. The real, from this perspective, ceases to be static, fixed, and assumes a relational postulate, since it is formed by emergent relational interactions (Chia, 1996), which are in flux and transforming the conditions for possibility of the world. Subjects and materiality gain their attributes in relationships, and the processes of organizing enact and re-enact these social entities in their existence (not $a$ priori, but in the relation of difference). Subjects produce and are effects of heterogeneous networks. The real is based on local actions, relationships and local orchestrations of relationships. Thus, the organizational process should be seen as an action, a verb, a temporary effect, rather than a consummate fact of a noun (Law, 1992).

Another characteristic of organizing is the ordering it produces. The act of ordering is constantly moving between becoming and being (Clegg et al., 2005). In this dynamic of being "between", “organizations" are provisionally ordered networks of heterogeneous material, whose resistance to ordering has temporarily been overcome (Chia, 1996). Organizing involves ordering and reducing complexity, and ordering means: ignoring, simplifying, and fixing what is complex for a moment in a stable form (Law, 1994). The perspective of Law (1992) reveals that organizing is an ontological, emergent and precarious act to present an ordered world. In this context, postmodern 
organizational analysis turns to the micro-practices and to organizing that is performed through an orchestration of actions, relations, interrelated relationships, generating divisions, spaces, frameworks, hierarchical arrangements, top, margins, inclusions, exclusions (Law, 1992; Chia, 1996). Organizing is, therefore, considering “organizations" as achievements, always in the active course of actions and the result of collective, precarious and partial processes (Law \& Cooper, 1995).

Organizing should not be understood as antagonist to disorder/chaos or purely as an ordering mode. "Chaos, disorder, and noise are not in opposition to, but are the precondition of organization" (Clegg et al., 2005, p. 154). The organization is a process of tension unfolding between order and disorder, which pluralizes and connects artifacts and subjects, humans and nonhuman elements. "The organization is not directed by intention (management), but it is always in-tension" (Law \& Cooper, 1995). It is a process of connecting what would otherwise be separate. Organizing is the knot, the fold, where order and disorder meet. It is the very process of transgressing the boundaries between the old and the new, the stable and the unstable (Clegg et al., 2005).

Practice-based studies (PBS) are one of those studies in the organizational area that support the idea of organizing in its processual and relational dimensions. Just as there is polysemy around OL, the term practice also has multiple meanings, from different sociological traditions. At least three meanings are commonly understood about practice: (a) Practice as a method of learning: people learn and perfect their ways of doing by repeating activities and by discussing shared ways of collective doing. "Practice makes perfect." (B) Practice as an occupation or field of activity: practice is taken as synonymous of field of activity, in which individuals develop and legitimize their knowledge, such as medical practice, for example. (c) Practice as the shared ways of doing something: practice is a processual concept to represent the logic of how subjects recognize, produce and formulate the modes and regulations of their daily activities (Gherardi, 2011, p. 48).

Gherardi (2005) defines practice "as a relatively time-stable and socially recognized way of ordering heterogeneous items into a coherent set" (p.34), based on phenomenological and ethnomethodological traditions. The nuances of this concept are based on the qualitative and holistic aspect of practice, on temporality and recurrence, on social recognition and on its form of collective ordering.

The qualitative and holistic aspects of practice refer to the question of how a set of activities acquires meaning and becomes recognized as a unit. The focus is not only on 
recognizing activities per se, but how these activities materialize in a situated context of action. On the aspect of temporality, for a practice to become as such it must be recursive over time to be recognized as a habitual mode of doing. This does not mean, however, that this reproduction happens mechanically. In this update that happens in the doing, there is always a dynamics of novelty and openness to change. Practices must be socially recognized, presupposing an institutional system that inscribes norms and allows such practices to be recognized, sustained and reproduced according to normative judgments negotiated among practitioners. The last aspect of the concept identifies practices as ways of ordering the world, because when they are performed they introduce modes of ordering of human and non-human agents. These ordering modes are unstable and embedded in a network of practices (Gherardi, 2005).

Gherardi's concept (2005) differs from the notion of practice synonymous with activities, of what is done. The concept is rather a way of assuming an epistemology of practice, which enables understanding the dynamics that occur in the process of a practice becoming a socially sustained mode of action in a given sociomaterial context in which it develops. In this perspective, practices are a way of understanding, of seeing certain forms of collectively doing, that is why an epistemology: a set of assumptions that guide knowing. If practice and action are theoretically different, there is a the need to understand how practice is constituted, its conceptual elements, what relationship it assumes with other practices and what effects it produces (Gherardi, 2010, 2011) stands out.

There are specific features that surround the notion of practice, which differentiate it from the notion of action. Imagetically, take the view of the fisherman or a fisherwoman in his/her boat in the river at the time of fishing. The network, the boat, the fish and the fisherman are elements that are constituted relationally in the act of fishing. The net, the boat and the fish make the fisherman and the fisherman constitute them in their differences. They mutually make each other up in the act of fishing. When fishing, the subject knows-in-action how to handle the nets, the best places in the river to launch them (depending on the time and weather conditions), feeling the river, positioning his body for the launching of the nets, the balance to keep it in the boat without turning it. There is a relationship between the knowing-fishing-in-action, which is re-actualized at each moment that the actions are done. Knowing how to do the movements, what materials to use, how to execute the next movements and the vocabulary proper to fishing, are things learned 
collectively in a network of relations, communicated between fishermen, and always transformed and updated during fishing-in-action.

There is a network of fishermen who share among them what one can know about fishing. They create codes, values, ways of doing that are transmitted and negotiated through time and space. Such in-action knowledge is not only situated at a particular moment in the network of relationships, but are also embodied activities that depend on sensitive knowledge (hands, eyes, ears, nose and mouth) that mobilize the perceptual faculties of the subjects in action, through the senses (Gherardi, 2011). Discursive practices shared in the relationship network of fishermen legitimize rules of operation, a shared language of their own and support the formation of aesthetic and ethical judgments within the fishing community itself. Such practices cannot be confused with the enunciative act itself. They are a "the set of anonymous, historical rules, always determined in time and space, which define, for a given epoch, and for a given social, economic, geographical or linguistic area, the conditions of exercise of the enunciative function" (Foucault, 1984, 153).

Beyond aesthetic knowledge and discourse, practices are shaped by the relationship between humans and materiality, understanding how humans and artifacts intertwine to perform practices. Artifacts, from a culturalist and constructivist view (which are different from ontological understandings of poststructuralist theories, such as actornetwork theory) can be the representation of stabilization and institutionalization of these practices. Stabilization is the expectation that actions will occur again and thus form a cultural-historical knowledge that supports practice, grounded in social and material elements. "Practice institutionalizes cultural processes, attributing to them ethical, aesthetic values for ways of doing and stabilizing them as a normative system (creating other artifacts such as codes, norms, audit systems, laws)" (Gherardi, 2011, p. 56).

Another concept of practice, close to that proposed by Gherardi $(2005,2011)$, is developed by Schatzki (2001, 2003, 2005, 2006). According to Schatzki (2001), practice "is a set of actions and sayings organized by an association of understandings, a set of rules and a teleoaffective structure that organize it, which can change over time in response to contingent events" (p. 61). Understandings, mentioned by the author in his concept, are intelligible and shared forms among a certain collective of how to perform certain action or activity. The intelligibility of these ways of doing has a close connection with the notion of learning and knowing, which will be discussed next. To be a known process, a practice 
needs to be learned and put into action by the subjects of the practice. The roles of relationships and language are central to spreading these shared understandings. The teleoaffective character of practices, mentioned by Schatzki (2001, 2006), refers to beliefs, desires, emotions and expectations imbricated in the way a person will act to reach certain ends (teleology).

Two important aspects of the notion of practice in Schatzki are time and space. The mesh of practices and orders is the site where social life happens and becomes (Schatzki, 2001). In this sense, the author argues that this social imbrication happens in a context, in that social space where practices take shape and are transformed. Practices take place within an objective and teleological time, the former regarding the succession of events and the later the history of the practices produced in the past-present-future time, which is embodied in the ways of doing and saying of the practice.

Practices are organized human activities (Schatzki, 2001, 2005), like economic and management practices, which happen through material arrangements (Schatzki 2003, 2005, 2006), indispensable in the articulation and doing of practices. In Gherardi's concept $(2005,2010)$, materiality is artifacts. In both ideas about practice (Gherardi, 2005, 2010; Schatzki, 2001, 2003, 2005, 2006), the presence of materiality or sociomateriality (Orlikowski, 2010) is crucial for the formation of practices. Material-practical arrangements comprise then: actions that constitute the practices; rules and what directs and guides actions; and the teleoaffective dimension, which concerns the emotive and oriented character of practices (Schatzki, 2005).

In this view, organization is a social phenomenon, a set of practices that are interwoven by material arrangements and a product of actions carried out in the midst of existing practices, guiding ways of doing and saying (Schatzki, 2005). The interconnectivity of practices presupposes that they do not happen independently, but constitute a network, a bundle of practices, a texture of practices (Gherardi, 2005). Practices represent shared relational dynamics that support the ontology of becoming (Cooper \& Law, 1995; Chia, 1996), since organizations must be apprehended as they occur in the practice of practices (Schatzki, 2006).

In order for a practice to be sustained collectively, it must be learned by the subjects, who will set such knowledge in motion in everyday actions. The next discussion is anchored in this way of seeing learning, flowing, as a process that takes place through action, relationships and practices - and constitutive of practices. 


\section{Learning Processes - Knowing and Learning}

Practice-based learning (PBL) is derived and composes the area in organizational studies that has practice as central axis. PBL considers knowledge and learning social, cultural phenomena that happen through practices. It is a possible way to overcome the existing gaps in organizational learning research, which turns to a perspective of processes as mental, individualized, segmented, instrumental and which do not consider social relations at their locus of analysis (Nicolini et al., 2003; Gherardi, 2005).

At first, the sociological contribution to organizational learning resided in the idea of learning as participation; then, reflexivity as a social dynamics of reproduction and, more recently, as practice. Organizational learning studies have reappropriated the concept of practice since the 1990 s and the early 2000 (Gherardi, 2011). Such appropriation allowed change in the understanding of knowledge, which is now considered knowing (Nicolini et al., 2003), meaning "knowledge in action, situated in a historical, social, and cultural context, and embodied in a variety of forms and materials (...). It is situated in the system of ongoing practices of action, as relational, mediated by artifacts, and always rooted in a context of interaction. Such knowledge is thus acquired through some form of participation, and it is continually reproduced and negotiated; that is, it always dynamic and provisional" (p. 1).

This conceptual rescue of PBL allowed knowledge to be understood as something that people develop collectively, which they do together, being inextricably interwoven with doing. Thus, learning moves from the "epistemology of possession" (Cook \& Brown, 1999) to the conception of knowing (Gherardi, 2011). The epistemology of possession is the understanding of the nature of knowledge as a thing, something that can be apprehended and held in the minds of individuals, as seen in some studies of "knowledge management". It is worth noting that the idea of knowing does not alienate the physical-mental activity necessary for knowledge to be put into action.

Cognitive perspectives, anchored in the management tradition, consider that knowledge is a mental realization, in which its ownership, transmission and accumulation are products of mental processes. Due to its reified nature, knowledge precedes action and is seen as a commodity (Gherardi, 2000; Flach \& Antonello, 2011). The epistemology of 
possession privileges explicit knowledge over tacit, and knowledge possessed by individuals over knowledge possessed by groups (Cook \& Brown, 1999).

Knowing is a complex process and intrinsically linked to the situated and contextual characteristic (Gherardi, 2000). Everything becomes relationship; the relationships of subjects to spaces, materiality, nature, to the subjects and materiality that form the economy, and so on. Cook and Brown (1999) argue that the term knowing is the epistemological dimension of the action itself, in such way that it is always in motion. According to the authors, knowing is not used in action or something necessary to action. It is part of individual and collective action. Such knowing is integrated into the subject of action and reflects knowledge (Flach \& Antonello, 2011).

Knowing is something that people do together and is a realization present in all worldly activities. To know is to be able to participate with competence requirements in a complex network of individuals and materials (Gherardi, 2001, 2009). This "knowinghow-to-do" refers to the ability to act in a given circumstance (Orlikowski, 2002). This characteristic of knowing refers to the knowledgeability or intelligibility of what can be known while it is being done. It is the knowledgeability of action (Orlikowski, 2002).

As the processes of knowing are part of action itself, the notion of learning as process allows the understanding that learning is not a thing or a means to store something, but a dynamic act intrinsically connected to doing. Doing-knowing-learning is an ontologically indissoluble triad. When we act we are awakening and mobilizing the knowing. In acting, we are thus learning, knowing-as-acting. Learning processes and knowing are mutually constitutive by action, as well as they enable the constitution of actions.

The concept of practice is different from the concept of action. The characteristic that differentiates practice from action is its recurrence in time, the history of practice (Gherardi, 2010). This does not mean that they are antagonist; on the contrary, they are intrinsically connected. In this way, practice is anchored in action and, consequently, in knowing. By using part of the notion of practice presented by Schatzki (2001), it is possible to understand the coengineering of a set of doings-sayings in organizing (which are the practices themselves): "it is a set of doings and sayings organized by an association of understandings (...)" (p. 61). Such knowing-in-practice is continually enacted through the subjects daily activities; it does not exist "out there" (embodied in objects, routines, etc.) or "in here" (circumscribed in minds, bodies or communities). Instead, knowing is a processual social achievement, constituted and reconstituted in 
everyday practices (Orlikowski, 2002). As it is performed at a moment, its status is always provisional. Even so, practice can be done repeatedly over time. Also, individual competence in knowing how to do is collective and based on the daily organizational practices.

Practice is then an object of doing, a time of doing and a socially recognized way of doing (Gherardi, 2010). In these dimensions knowing takes place through learning which is inherent to doing - a knowable doing - and such knowable doing is sustained by the appreciative social norms of this doing (if things are being done according to what is aesthetically accepted and shared by the subjects of a practice like, for example, what is correct, beautiful, ugly, usable, etc.). To summarize, practices are collective ways of doing (Gherardi, 2010). The act of learning is not something done for organizations, or something that organizations do. On the contrary, learning and organizing are seen as mutually constitutive and unstable acts (Clegg et al., 2005). This ontological coengineering of organizing-knowing-learning will be presented in the next and last discussion.

\section{Discussion and Conclusion: Organizational Learning Processes and their Conditions for Possibility}

An intellectual movement against simplifications has been developed in sociological studies. In order to shorten certain analytical paths, some researchers may treat the world, phenomena, in a simplified and domesticated way. But how do we know if the phenomenon under study is complex? According to Mol \& Law (2002), complexity exists when things relate but do not add up; when certain events do not happen linearly in time; and when the phenomenon shares a space, but cannot be easily mapped.

It is a challenge to deal with what is unforeseen or with what may be predictable but difficult to be dealt with. The modern world is full of reductive and simplifying scientific descriptions that are used as basis for actions on a given situation. Academic texts tend to organize complex phenomena from a "global view" to demonstrate what is being addressed. Rather linear models or schemes are created, explaining the phenomena from a sequence of events, with one event necessarily after the other. These academic texts, in general, can speak of and explain unconventional and sometimes strange situations, in a calm and non-disturbing way (Mol \& Law, 2002). This is a way of taming reality, or rather the (multiple) realities that are practiced, performed, and filled with complexities. This 
does not mean, however, that other ways of understanding phenomena are not valid. On the contrary, they bring innumerable contributions. What we would like to call into question in this article is that we should think of the phenomena in a less simplistic way, assuming their complex dynamics.

Whether in organizational or societal contexts, situations can be considered complex phenomena (Mol \& Law, 2002). Considering the aspects proposed by the authors, events in our lives are a multiplicity of relationships that develop among heterogeneous actors, who intersect, affect each other, separate and may interlace again. However, it is not possible to state that these phenomena are conceived as the sum of these relations. Such relationships are intertwined, not summed up, and do not occur linearly in time with a predictable sequence of actions. When the analysis of a particular phenomenon is characterized from a perspective of relationships and networks, these situations can happen in different places, in numerous territories. However, the relationships that are established are not easily mapped, as they can happen beyond the boundaries of these places.

Reality consists of a normality that is not normal or natural, but negotiated and composed of relationships of inequality, power and force. Many social dynamics are vague, diffuse, non-specific, unstable, confused, untidy, messy (Law, 2004). It is about dealing with the chaotic and disorderly, while modern science predicts a structured and orderly project in the understanding of social (Law, 1994). Disorders, confusing dynamics and inequalities are present in social relations. Learning to organize is one of the possibilities for actors to overcome the chaotic and unequal conditions formed by heterogeneous social relations in situations faced on a daily basis.

At this point in the theoretical discussion, we considered important to construct a central idea for this theoretical essay, which is learning in organizing; referring to the ontological coengineering of the learning-knowing-organizing. From the 1950 s onwards, the terms learning and organization flirt with their theoretical link (Cangelosi \& Dill, 1965; Cyert \& March, 1963). They have already been conjugated in different ways: changing their order (organizational learning - OL, and learning organizations - LO) (EasterbySmith \& Lyes, 2011) and having their conjunction treated as an oxymoron, as opposing and contradictory ideas side by side (Weick \& Westley, 2012).

With the emergence of the notion of organizing, inspired by the postmodernist turn and post-structuralist ideas (Chia, 1996; Calás \& Smircich, 1999), organization ceases to be 
understood as a reified entity and becomes a process of organizing, an unstable flow of relationships and collective actions linked to the act of organizing. Thus, organizing is a way of considering "organizations" as achievements, which are always in the active course of actions and are the results of collective, precarious and partial processes (Law \& Cooper, 1995). According to this understanding, the organization "is an achievement, a process, a consequence, a set of resistances overcome, a precarious effect” (Law, 1992, 390). Following this idea of achievement, organizing is collective actions intelligible in a human and non-human ecology (Gherardi, 2009).

These collective actions generated from the relationships among actors of the organization can generate practices, which are understood as "a set of doings and sayings organized by an association of understandings, a set of rules and a teleoaffective structure that organize it, which can change over time in response to contingent events" (Schatzki 2001, p. 61). The recursiveness of practices is what enables the reproduction of the "organization" every day (Gherardi, 2011). The historical aspect of practice is explicated by the concept of teleological time, which refers the history of the practices produced in the past-present-future time, embodied in the ways of doing and saying of the practice. Likewise, practices generate repetitions (which can always be performed in different ways) and stabilizations, having ordering processes as relational and performative effects of these practices (Law \& Lien, 2012). It is a way of establishing unstable ordering on how to do things.

There is no pure or sole order. There are ordering processes (Law, 1994). It is socially shared that if our organizations, our lives, and the social theories are properly ordered, everything is going well. Disorder is seen as threat and distraction. The analysis of the ordering processes, on the contrary, assumes disorder, complexity, as being a sign of the limits of a given order. The social world - which is not "purely social" - is complex and misaligned. Order is not secure and unlimited. It is product and effect of performative actions, of practices established among heterogeneous actors that interact, having certain duration in flux (Law, 1994, 2004).

The idea of structure changes into a set of relations and performative and practical actions, avoiding the presupposition of a single and founding order. The components of structures such as hierarchies, information flows, power relations are not always certain consequences of a process of ordering that is heterogeneous and material (Law, 1992). Organizing is emerging, moving phenomena that shape their own flows (Law, 1994). There 
is performative creativity in these relations. In management research, in general, the aim is predominantly to understand formal organizations already structured and their rather predictable dynamics.

Together with the notion of organizing is the notion of learning. A promising ontological and epistemological view in terms of organizational learning studies (Antonello \& Godoy, 2011; Godoy \& Antonello, 2011; Flach \& Antonello, 2011) is practicebased learning (PBL). It brings freshness to this theoretical discussion (Nicolini et al., 2003), claiming that learning can be better understood as a social process in which learning and knowing are mutually and simultaneously constituted at the moment actions are performed (Gherardi, 2001, 2009, 2010, 2011; Nicolini et al., 2003). According to the authors, knowing is knowledge in action, historically, socially and culturally situated where it happens, being apprehended in a variety of ways and means. Situated in a set of continuous practical actions, it is relational, mediated by artifacts and always rooted in a context of interaction. It is acquired by forms of participation, negotiated and always provisional.

Organizing is joined with the dynamics of knowledge in the flow of these events. Learning processes are this knowledge performed and learned in the development of actions and relationships. Actions that are in the flow of everyday events trigger and mobilize knowledge in doing, given the ubiquity of doing-knowing-learning. From this processual dynamics, knowing, learning and organizing are ontologically intertwined, coengineered and juxtaposed actions, not necessarily created in this order. The process characteristic is to be in movement, with the instabilities, tensions and contradictions which occur in relations between actors. This back-and-forth movement means that the doing-knowing-learning triad can be reviewed and reconsidered in both its order of occurrence and its incidence. Therefore, both processes are understood here as processes of organizational learning, because of their interlaced character.

This idea expresses the ubiquitous nature of the knowing-learning in organizing; expresses that to materialize the organizing, knowledge is necessary; that when we are organizing something, knowledge is being performed, learned and transformed into action; that knowing-learning is not something done in organizations or for organizations, but rather while organizing. It is possible to exemplify it in the following consideration: subjects learn through their heterogeneous relationships and experiences, and this knowledge is performed in everyday actions and practices, being relational, dynamic and 
provisional. Consider an academic activity, such as writing an article, to elucidate this process of learning-knowing in action. Writing an article may sometimes seem like an identical exercise. This knowledge is performed at the moment of writing, on a particular occasion, with a set of relationships. Even if a person has written more than one article in his or her career, this performed knowledge will always bring some different element: a set of specific knowledge, rules that must be respected for publication in certain journals, the subject's posture on the computer, dynamics of the typing, his/her life moment, etc. The act of writing an article may resemble other events already practiced, but it will always be different and unique. In this sense, organizing presupposes diverse knowledge performed together with the act of organizing, producing certain ordering and stabilizations. One cannot exist without the other. They happen while being and doing.

In this attempt of multiple possibilities, three basic aspects with potential to contribute to the understanding of organizational learning stand out: the idea of network as an associative relational process; the heterogeneous nature of these relations; and political ontology, which concerns the negotiated and contested modes of relational and associative dynamics. This point of view can contribute to the analysis of these complex phenomena for understanding them in a fluid and processual way; for being based on generative, performative and practical actions; for assuming that the associations between the actors take place in a dynamic manner, forming meshes, webs, networks of relationships (sometimes stabilized and organized); for admitting that knowledge is performed in actions and from relationships; for considering that such relations are heterogeneous; and for paying attention to the relations of power, considering that the conditions for possibilities are not given but produced. In the next paragraphs, there will be discussions on the contributions of this positioning to the understanding of organizational learning.

One contribution is the conception of the organizational learning process in a network, in a mesh or web of relationships. Law \& Singleton (2013) state that everything is entangled with everything else. Things are interrelated. According to the authors, the metaphor "network" does not need to be fixed. It can be treated as "network of relations", "actor-network", "rhizome", "mesh". What is important are the relationships that define and characterize the actors involved in the network that unfolds, in uncertain and unsecured ways (Law \& Singleton, 2013). The notion of relationship differs from the notion of interaction. To relate is to provoke affectations in a performative act, to constitute the 
other $^{1}$. Interacting denotes superficiality in the contact between actors. Moreover, the notion of network dissolutes the conception of levels (micro and macro), because regardless of the "size" attributed to things - large or small, wide or narrow - they must be studied through and at the "level" of the relationships which compose and produce them. In this sense, empirical research can point out how certain actors are aggregated and relate in certain practices; how others are excluded from certain relational processes. These aspects are relevant in empirical research on disaster situations.

The heterogeneity of these actors is also emphasized. The aim here is not to propose an integrative approach, but to value the analysis of the social in conjunction with materiality, with the elements of nature that affect and constitute each other.

This affectation and coproduction must be examined in a denatured way, knowing that the conditions for possibility are not given, but can be contested (Mol, 1999). Regarding this aspect, we would be giving an opportunity to analyze the relations of power and strength that are configured in the relationships between the actors. Power not as something one holds, but as an effect of such relationships.

Considering the contribution of the authors who worked on the idea of organizingknowing-learning as process (Gherardi, 2001, 2005, 2009, 2010, 2011; Nicolini et al, 2003) and through practices (Schatzki, 2001, 2006; Gherardi, 2005, 2011), processes of organizational learning are ways of collectively doing, moving and unstable, knowable by learning and by knowing ${ }^{2}$. They are established in a network of heterogeneous relations in multiple forms of spatialities ${ }^{3}$, and can get inscribed and form texture of practices, whose conditions for possibilities for their achievement and participation are not given, and can also serve as a means to combat, overcome inequalities, and form other doings and practices.

This view differs from knowing in some conceptual elements: a) In the ideas of "situated" and "context", given that we introduced a different notion of spatiality, which

${ }^{1}$ Based on the tradition of semiotics, Law (2002, p.91) claims that the meaning of an actor depends on its relations and, specifically, relationships of difference between the elements of the relationship. The author mentions, for example, that the cat and the dog achieve a difference of meanings by virtue of the difference of one in relation to the other. Thus, the meaning of a term is determined by networks of relationships of difference. The meaning of the actor is a relational effect.

${ }^{2}$ Knowledge in action, historically, socially and culturally situated where it happens, being apprehended in a variety of ways and means. Situated in a set of continuous practical actions, it is relational, mediated by artifacts and always rooted in a context of interaction. It is acquired by forms of participation, negotiated and always provisional (Nicolini et al., 2003).

3 According to Law (2002), actors and objects are enacted, performed in a multi-topological way (topology originates in mathematics and studies the geometric properties of a body, which are not altered by continuous deformation. See De Laet \& Mol (2000) on water pumps in Zimbabwe), and are dependent on the intersections between different spatialities. Euclidean space, networks and fluid spaces. 
turns into multiple spatiality or multiple forms of spatiality (Euclidean space, networks and fluid spaces). Law (2002) claims that human and non-human actors are produced at the intersection, between different spatialities, and they perform such different spatialities in the same way. Objects and entities of the "context" become actors in a network of relations.

b) In the notion of "mediated by artifacts", considering that the actors are heterogeneous and, in this way, that elements of nature and materiality, for example, are actors of this network, generating performative actions. This notion differs from the notion of artifact in which materiality only circumscribes the "cultural meanings" shared among human actors or mediate actions.

c) In the discussion about the political ontology of organizational learning processes (Mol, 1999), referring to the unequal conditions for the insertion and participation of some actors in the organizing and in the practices that can be formed from them. In addition, such processes can serve to challenge and form new practices.

Regarding the suggestions of Antonello \& Godoy (2011) on the four characteristics that should be further studies and discussed on organizational learning (learning level, goal neutrality, notion of change, processual nature of learning), we highlighted two: the understanding of learning through relationships (level of learning) and by means of its processual nature (processual nature of learning). Thus, the idea of this theoretical essay is based on these characteristics and seeks to contribute with one more, now added to the list of Antonello \& Godoy (2011), which is the political characteristic of learning, its conditions for possibility and imbalances in the relations of power and strength that take place in this process of learning to organize. A reflective perspective for learning.

Traditionally, OL studies and research focus on two aspects: the content of learning (what is being learned) and the way people learn individually and collectively (how learning is happening) in organizational contexts. Inspired by the "postmodernist" and "post-structuralist" ideas, the purpose of this essay is to look at another aspect that can contribute to the reflective and political perspective of learning: understanding how OL is configured in relationships is exploring the conditions for possibility for processes of organizational learning to happen in certain arrangements of relations.

The discussions presented represent some possibilities. Incomplete, imperfect and non-exhaustive. Inspirations and curiosities that instigate me to search for an empirical understanding of organizational learning in different fields of study, which are also effect 
of actions and relationships of actors. Bearing in mind that the theoretical attempt presented here will serve only as an inspiration for the emergence of other writings, of other understandings. 


\section{Referências}

Antonello, C. S., \& Godoy, A. S. (2011). Aprendizagem organizacional no Brasil. Bookman Editora.

Argyris, C., \& Schon, D. A. (1978). Organizational Learning: A Theory of Action Perspective Addison-Wellesley. Reading, Massachusetts.

Bapuji, H., \& Crossan, M. (2004). From questions to answers: reviewing organizational learning research. Management learning, 35(4), 397-417.

Cook, S. D., \& Brown, J. S. (1999). Bridging epistemologies: The generative dance between organizational knowledge and organizational knowing. Organization science, 1O(4), 381-400.

Calas, M. B., \& Smircich, L. (1999). Past postmodernism? Reflections and tentative directions. Academy of management review, 24(4), 649-672.

Cangelosi, V. E., \& Dill, W. R. (1965). Organizational learning: Observations toward a theory. Administrative science quarterly, 175-203.

Chia, R. (1996). Organizational analysis as deconstructive practice (Vol. 77). Walter de Gruyter.

Clegg, S. R., Kornberger, M., \& Rhodes, C. (2005). Learning / becoming / organizing. Organization, 12(2), 147-167.

Cooper, R. (1976). The open field. Human Relations, 29(11), 999-1017.

Cooper, R., \& Burrell, G. (1988). Modernism, postmodernism and organizational analysis: An introduction.

Cooper, R., \& Law, J. (1995). Distal and proximal vision of organization. Studies of Organizations in the European Tradition, 237-74.

Crossan, M., \& Guatto, T. (1996). Organizational learning research profile. Journal of organizational change management, 9(1), 107-112. 
Cyert, R. M., \& March, J. G. (1963). A behavioral theory of the firm. Englewood Cliffs, NJ, 2, 169-187.

De Laet, M., \& Mol, A. (2000). The Zimbabwe bush pump: Mechanics of a fluid technology. Social studies of science, 3o(2), 225-263.

Dodgson, M. (1993). Organizational learning: a review of some literatures. Organization studies, 14(3), 375-394.

Duarte, M. F., \& Alcadipani, R. (2016). Contribuições do organizar (organizing) para os estudos organizacionais. Organizações \& Sociedade, 23(76).

Easterby-Smith, M. (1997). Disciplines of organizational learning: contributions and critiques. Human relations, 5O(9), 1085-1113.

Easterby-Smith, M., \& Araujo, L. (2001). Aprendizagem organizacional: oportunidades e debates atuais. Aprendizagem organizacional e organizações de aprendizagem: desenvolvimento na teoria e na prática. São Paulo: Atlas, 15-38.

Easterby-Smith, M., \& Lyles, M. A. (Eds.). (2011). Handbook of organizational learning and knowledge management. John Wiley \& Sons.

Fiol, C. M., \& Lyles, M. A. (1985). Organizational learning. Academy of management review, $10(4), 803-813$.

Flach, L., \& Antonello, C. S. (2011). Organizações culturais e a aprendizagem baseada em práticas. Cadernos EBAPE.BR, 9(1), 156-176.

Foucault, M. (1984). História da sexualidade I: a vontade de saber; tradução de Maria Thereza da Costa Albuquerque e JA Guilhon Albuquerque. Rio de Janeiro, Edições Graal.

Gherardi, S. (2000). Practice-based theorizing on learning and knowing in organizations. Organization, 7(2), 211-233.

Gherardi, S. (2001). From organizational learning to practice-based knowing. Human relations, 54(1), 131-139. 
Gherardi, S. (2005). Organizational knowledge: The texture of workplace learning. John Wiley \& Sons.

Gherardi, S. (2009). Knowing and learning in practice-based studies: an introduction. The Learning Organization, 16(5), 352-359.

Gherardi, S. (2010). Telemedicine: A practice-based approach to technology. Human relations, 63(4), 501-524.

Gherardi, S. (2011). Organizational learning: The sociology of practice. Handbook of organizational learning and knowledge management, 2, 43-65.

Gherardi, S., \& Nicolini, D. (2001). The sociological foundations of organizational learning. Handbook of organizational learning and knowledge management, 2, 35-60.

Godoy, A. S., \& Antonello, C. S. (2011). Cartografia da aprendizagem organizacional no Brasil: uma revisão multiparadigmática. Aprendizagem organizacional no Brasil. Porto Alegre: Bookman, 51-77.

Law, J. (1992). Notes on the theory of the actor-network: Ordering, strategy, and heterogeneity. Systems practice, 5(4), 379-393.

Law, J. (1994). Organizing modernity (pp. 100-104). Oxford: Blackwell.

Law, J. (2002). Objects and spaces. Theory, culture \& society, 19(5-6), 91-105.

Law, J. (2004). After method: Mess in social science research. Routledge.

Law, J., \& Singleton, V. (2013). ANT and Politics: Working in and on the World. Qualitative Sociology, 36(4), 485-502.

Levitt, B., \& March, J. G. (1988). Organizational learning. Annual review of sociology, 14(1), 319-338.

Mol, A. (1999). Ontological politics. A word and some questions. The Sociological Review, 47(1_suppl), 74-89.

Mol, A., \& Law, J. (2002). Complexities: Social studies of knowledge practices. Duke University Press. 
March, J. G., \& Olsen, J. P. (1975). The uncertainty of the past: Organizational learning under ambiguity. European journal of political research, 3(2), 147-171.

Nicolini, D., \& Meznar, M. B. (1995). The social construction of organizational learning: conceptual and practical issues in the field. Human relations, 48(7), 727-746.

Nicolini, D., Gherardi, S., \& Yanow, D. (2003). Introduction: Toward a practice-based view of knowledge and learning in organization. In. Knowing In Organizations: A PracticeBased Approach. M.E. Sharpe.

Orlikowski, W. J. (2002). Knowing in practice: Enacting a collective capability in distributed organizing. Organization science, 13(3), 249-273.

Orlikowski, W. J. (2010). Practice in research: phenomenon, perspective and philosophy. Cambridge handbook of strategy as practice, 23-33.

Schatzki, T. R. (2001). Introduction: practice theory. In. Cetina, K. K., Schatzki, T. R., \& Von Savigny, E. (Eds.). The practice turn in contemporary theory. Routledge.

Schatzki, T. R. (2003). A new societist social ontology. Philosophy of the Social Sciences, 33(2), 174-202.

Schatzki, T. R. (2005). Peripheral vision: The sites of organizations. Organization studies, 26(3), 465-484.

Schatzki, T. R. (2006). On organizations as they happen. Organization studies, 27(12), $1863-1873$.

Shrivastava, P. (1983). A typology of organizational learning systems. Journal of management studies, 2O(1), 7-28.

Weick, K. E., \& Westley, F. (2004). Aprendizagem organizacional: confirmando um oximoro. Handbook de estudos organizacionais. São Paulo: Atlas, 3, 361-388. 